\title{
The FMEA-Risk Analysis of Oil and Gas Process Facilities with Hazard Assessment Based on Fuzzy Logic
}

\author{
Eduard Arkadievich Petrovskiy ${ }^{1}$, Fedor Anatoliievich Buryukinn ${ }^{2}$, Vladimir Viktorovich Bukhtiyarov ${ }^{1}$, Irina \\ Vasilievna Savich $^{1} \&$ Mariya Vladimirovna Gagina ${ }^{1}$ \\ ${ }^{1}$ Oil and Gas Institute, Department of Technological machines and equipment oil and gas industry, Siberian \\ Federal University, Krasnoyarsk, Russian Federation \\ ${ }^{2}$ Oil and Gas Institute, basic Chemistry and Technology of Natural Fuels and Carbon Materials, Siberian Federal \\ University, Krasnoyarsk, Russian Federation \\ Correspondence: Fedor Anatoliievich Buryukin, Oil and Gas Institute, basic Chemistry and Technology of \\ Natural Fuels and Carbon Materials, Siberian Federal University, Krasnoyarsk, Russian Federation.
}

Received: February 6, 2014

Accepted: February 13, 2014

Online Published: March 24, 2015

doi:10.5539/mas.v9n5p25

URL: http://dx.doi.org/10.5539/mas.v9n5p25

\begin{abstract}
The paper considers the practical application of the Failure Mode and Effect Analysis method to assess the operational reliability of the oil refineries' equipment, which is a pressing problem for the oil-producing regions and countries. Oil refineries are hazardous industries, and therefore the construction, adaptation and testing of effective risk analysis methods is an important task. The solution to this problem provides the basis for corrective management action to reduce the probability of damage from accidents to humans and the environment. The method is based on the detection probability of inconsistencies and involves elaborate ways to increase the reliability and security through risk analysis method. The approbation is performed for the Failure Mode and Effect Analysis method to assess the reliability based on the detection of defects typical to oil and gas facilities. The basic steps of the Failure Mode and Effect Analysis method are provided and show the possible options for scaling required to obtain quantitative risk assessments. The result was the quantitative risk assessment for oil transportation facilities. The supporting method for quantifying risk in emergency situations on the equipment are encouraged to use a fuzzy logic approach. The paper describes the main steps of this approach shows its applicability and the possibility of formation for quantitative estimates of the hazards of various defects in the equipment.
\end{abstract}

Keywords: risk management, reliability, risk analysis, oil and gas, defect isolation

\section{Introduction}

\subsection{Introduce the Problem}

Modern economic development in many regions of the world is closely linked with the development of production, transportation and processing of minerals, including oil and gas. However, now it becomes obvious that without improving the production efficiency, transportation and processing of mineral resources is not possible or very difficult further to support the positive dynamics of the development in this industry. Under these circumstances, the priority comes to the problems of low efficiency and unsystematic use of technological machinery and equipment in the oil and gas industry. Solving these problems requires consideration of issues related to ensuring the reliability of technological machinery and equipment, timeliness of diagnosis for their condition and forecasting parameters of the corresponding processes. Substantial progress in the areas mentioned above can be achieved through the development, deployment and use of modern management systems, diagnostic and prognostic indicators of technological equipment reliability. The basis of such systems tends to put the algorithmic core and model of the production equipment and technological processes system. The quality of the solutions formed by the algorithmic core and capabilities of the used models of the process equipment systems and processes depends on the efficiency of using intelligent systems, and thus ultimately the performance, reliability and efficiency ("return") of industries in which they are used, and which now are the support for the oil and gas industry development.

Oil refineries have a wide range of process equipment: vessels, pipelines, heat exchangers, pumps, columns, 
separators - and this is not an exhaustive list. Oil refinery equipment refers to heavy duty in connection with the operation in aggressive technological environment: highly corrosive activity, high temperature and pressure, varying strain and temperature deformation and influence of the chemical elements (hydrogen sulfide, hydrogen, hydrogen chloride, acid and other) (Burgherr et al., 2012). In addition, the fluctuations of raw materials and reagents, vibrations of adjustable parameters (temperature, pressure, etc.), fluctuations of external factors (supply voltage, temperature, pressure process steam, etc.), as well as external mechanical influences (hydraulic shock, vibration) are inevitable. Under the influence of all the above factors as well as the process of physical ageing and wear, damage to the equipment parts occurs. The reached critical level of damage, resulting from the operation, results in the destruction of the working condition of the equipment and, therefore, leads to its failure (Tweeddale, 2003). In the context of such operation and accidents, the main task is to predict the emergence and development of defects (Barends et al., 2012; Smith, 2011). Achievement of this taks required principally new approaches aimed at predicting the safety and reliability, as well as effective methods of reducing potential risks and negative consequences of failures. One of such methods is the analysis of the types and consequences of potential failures (Failure Mode and Effect Analysis - FMEA) (Barends et al., 2012; Medikonda et al., 2011).

To date, the FMEA-analysis is one of the tools to quantify risk coefficient.

Prediction of defects and failures, analysis of outcomes and prevention of their occurrence is the main objective of this method. The FMEA method allows identifying potential inconsistencies, their causes and consequences, assessing the risk of their occurrence and taking the measures to eliminate or reduce the probability of their occurrence. Reducing the risk and uncertainty of regulation for the probability of occurrence for the defect is the main goal of this method (Xiao et al., 2011).

The FMEA method eliminates errors and related faults, and, therefore, eliminates the significant costs to eliminate inconsistencies. Application of the FMEA method for processes or structures allows solving the following tasks (Chen-qin \& Yue, 2012):

- detection of bottlenecks;

- completion of technologies/structures to the most appropriate in terms of reliability and safety indicators, develop proposals for keeping the design and technological reliability;

- $\quad$ reducing the cost for removing defects;

- $\quad$ preventing the latent defects;

- preventing threatening situations and/or minimizing their consequences;

- achieving the required performance security, environmental impact and reliability.

The aim of the study presented in this paper is the testing for the FMEA method of the risk assessment for probability of inconsistencies, their causes and consequences of equipment involved in technological processes of primary and secondary oil refining.

\subsection{Relevant Scholarship}

In various industries, including oil and gas, integrated assessment of safety performance, reliability of process equipment, numerical risk assessment and prediction of the consequences of accidents can use a variety of approaches (Petrovsky \& Elrikh, 2012). Below is a brief overview of some of them that are seen as the most relevant and which more precisely correspond to the current state of science, engineering and technology.

The paper by (Hekmatpanah et al., 2011) proposes to use the FMEA method as a tool for warning of potential problems and identifying their causes for production lines of oil refineries. The authors demonstrate the possibility of a significant reduction in the risk of defects after the corrective measures planned by the results of FMEA. However, the FMEA method is not exhaustive, and there are quite a number of alternative approaches, including for quantitative risk assessment and management. Thus, for risk analysis, the paper by (Shahriar et al., 2012) proposes an approach based on the use of fuzzy logic. However, the authors used a model adapted to the specific problem to be solved - risk management for oil and gas pipelines. There are examples of successful use of a combination of strategies based on fuzzy logic and machine decision tree to estimate the probability of accidents on oil pipelines (Yuhua \& Datao, 2005). In general, the problem of risk management in oil and gas transportation and other production chains approaches to its solution are discussed in detail (Farrell \& Brandt, 2006; Khan et al., 2008).

More traditional, classical approaches are also applied, which, however, shall be also localized for use as an algorithmic framework for risk assessment and management. Thus the paper by (Yousef et al., 2014) uses the method of Six Sigma for increasing appropriate indicators of welding production at oil and gas facilities. Using 
this approach, the authors developed practical recommendations to improve the organization of welding production and quality control for the works undertaken.

The paper by (Skogdalen et al., 2011) contains developed and explained the special security indicators based on similar terms used by the Norwegian oil companies. The possibility of their use in the oil and gas industry as a whole is demonstrated as well. In recent years, considerable attention is paid to the development and adaptation of methods to assess the safety and control methods based on risk management in offshore fields (Khan et al., 2002).

An exhaustive review of approaches to assessing reliability and probability of accidents and risk management methods is provided in the paper by (Zio, 2009).

\section{Methodology and Methods}

\subsection{The Proposed Approach to Integrated Assessment of the Risks and Hazards}

\subsubsection{FMEA}

When using the FMEA-method, it is possible to estimate the operational reliability and risks of equipment that can lead to equipment malfunction or reduce its service life, to quantify the risk coefficient, identify potential reasons for these discrepancies and to develop corrective actions before the failure, thereby to prevent accidents and reduce costs for their elimination.

Work on the practical application of FMEA involves several steps according to the flow diagram shown in Figure 1. 


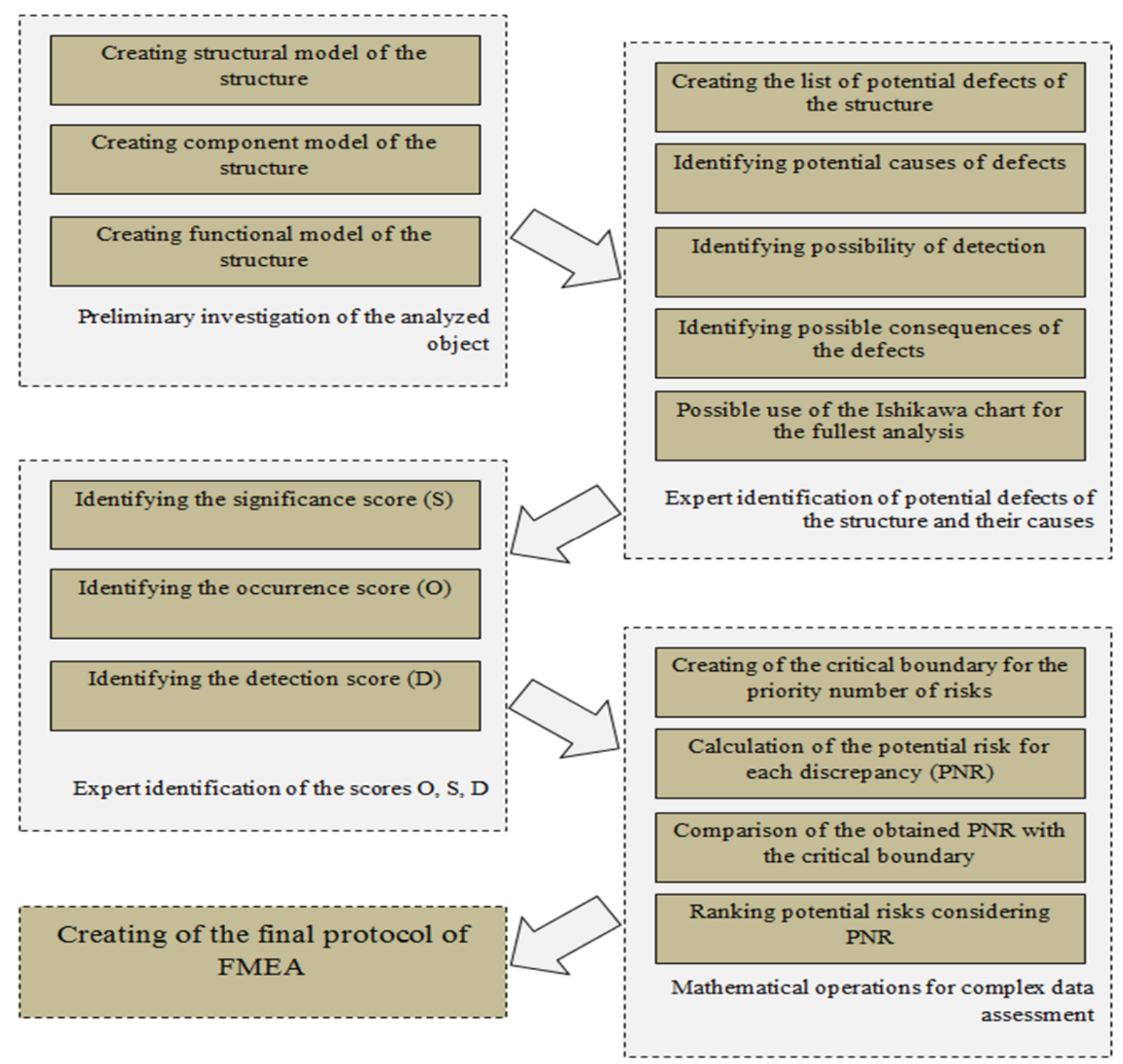

Figure 1. Stages of FMEA

The initial stage of the analysis assumes a comprehensive study of the equipment located in the technological chain of oil refining. Component (to determine the components of this design), structural (analysis of the relationship between structural elements) and functional (analysis of the components of the nodes/details on the implementation of the described functions) analyses of the equipment is made.

These studies are necessary for learning the best overall structure, the functions of individual elements and their functional interaction. Based on the data, all the features of the equipment are analysed as per the requirements of technical documentation.

Next, each item shall have identified the potential defects for the life cycle of the equipment, which may occur for various reasons, using the existing classifications of failures and engineering analysis. With further study, a list of all potential discrepancies to the object under study is made. In the third stage of the FMEA-analysis, in accordance with the intended conditions of use, maintenance and repair, the potential causes for each of the possible discrepancies (appropriate use of the Ishikawa diagram) shall be identified.

All described species of potential defects have their consequences defined.

Then the quantitative assessment of factors affecting the reliability and quality is made - risk assessment criteria: 
- (S) - coefficient determining the value/severity of failures for each case of discrepancy,

- (O) - coefficient taking into account the probability of failure. The probability of occurrence is determined for each potential cause of the defect.

- (D) - coefficient taking into account the probability of detecting defects during the operational phase until occurence of its consequences or the probability of a skipped failure. It is determined for each defect and each cause.

Quanitative evaluation of $S, O$ and $D$ factors shall be made on a scale evaluation form for each of the factors separately. Based on the calculated coefficients, the hazard ratio (priority number of risks, PNR) is determined:

$$
P N R=S^{*} O * D,
$$

where $\mathrm{S}$ is the severity of failures for each discrepancy, $\mathrm{O}$ is the probability of failure; $\mathrm{D}$ is the probability of defect detection until its consequences or the probability of a skipped failure. It is determined for each defect and each cause.

PNR shows which possible failures (and their causes) are the most significant and, therefore, for which corrective and preventive measures shall be taken to reduce the probability and consequences of a risk event.

Further, there is a ranking of defects and failures for which the PNR exceeds the critical limit. For them, corrective actions shall be developed first. The main objective for the development of corrective actions is to reduce one of the factors - the risk assessment criteria: severity, probability of occurrence and probability of detection.

Graphically, the ranking of failure modes according to PNR can be represented as Pareto charts, designed to identify the main problem and reflect in order of importance of the unwanted results associated with the quality and safety of equipment, supplemented cumulative curve used to rank the different groups of the studied parameters. The analysis of the diagram provides the information needed to develop the necessary administrative decisions on the development of corrective actions.

The final step is to make a table to reflect the main results of the FMEA analysis. Following the results of the analysis, the development of technical (design and technological) solutions is made. The solutions are aimed at preventing the consequences of failure, minimizing the probability of occurrence for the identified potential failures by improving the design, operation rules, systems maintenance and repair, improvement of methods for the quality control and the introduction of special measures to prevent, detect and eliminate the defects, etc.

It is recommended to consider the corrective measures in the following sequence:

- eliminate the cause of the defect. By changing the structure or the process, reduce the possibility of a defect occurrence (O parameter is decreased).

- prevent the defect occurrence. With the help of statistical control, prevent the defect occurrence $(\mathrm{O}$ parameter is reduced).

- reduce the influence of the defect. Reduce the impact of the defect occurrence on the customer or the subsequent process to reflect changes in the timing and cost (S parameter is reduced.

- facilitate and improve the accuracy of detecting the defect. Facilitate the identification of the defect and subsequent repair (D parameter is reduced).

\subsubsection{Quantitative Risk Assessment Using Fuzzy Logic}

One of the FMEA stages supposes a need for expert quantified assessment of the risk. A method based on fuzzy logic shall be used for further improvement of the efficiency and automation of formation of such quantitative assessments. This method allows eventual forming a calculated mathematical model to quantify precisely the hazards of defects in equipment, which is applicable in the processing chain.

Currently, quantitative measure of hazard is adopted risk (Guzman and Asgari, 2014). A risk refers to the frequency of emergencies and assessing the man-made refers even to the value of the hazard caused by the emergency. If the consequences are unknown, the risk is the probability of only certain combinations of adverse events.

It is proposed to determine the level of hazard of an emergency at thee equipment used in the technological assessment of the possible consequences in the event of defects at the processing facilities. The ability means the physical feasibility of an event or process, in this case - the physical feasibility of the process equipment malfunction as a result of the defect occurrence. 
The measure of the possibility is the value of fuzzy coefficient of hazard, which is associated with a clear value of the normalized integral index of fuzzy sets (Zadeh, 1997; Mendel, 2001).

The risk of an emergency is determined, including, by the risk of defects, which are the cause of its occurrence. Thus, the problem of determining the level of hazard is divided into two stages. The first stage determines the level of hazard of technological defects that may occur in the technological object (in general, a process system). The second stage using fuzzy logical conclusion is determined by the risk of failure on process equipment, to which the considered defects and damages can lead (Khaleghi et al., 2013; Aras et al., 2014).

The most hazardous are the defects that can lead to accidents with an explosion, fire and release of toxic substances (Saidi et al., 2014). Therefore, the main destructive factors (DF) taken into account when determining the level of hazard, are listed in Table 1.

Table 1. Destructive factors and their main parameters

\begin{tabular}{ll}
\hline Destructive factors & Parameters \\
\hline Shock wave & Excessive pressure in the shock wave front \\
Heat radiation & Heat transfer rate \\
Toxic loads & Concentration of a toxic substance \\
\hline
\end{tabular}

The problem is reduced to the establishment of the relationship between the destructive factor (i.e., a occurrence of hazard) and the possible destructive effect on the technological system. Before defining the relationship, we shall formally describe the destructive factors, in case of an accident, as well as describe the extent possible malfunction of the process equipment

\section{Determining the level of hazard for an emergency situation}

Step 1. Detect defects, which occurrence is possible on the considered process equipment. Determine how hazardous are these defects, identify the relevant factors affecting, in the case of an emergency.

Step 2. A formal description of each type of hazard is conducted, taking into account the impact of a destructive factor onto the technological system. The description is made using linguistic variables, and the construction of linguistic variables is made by means of indirect methods of expert assessments. Thus, a measuring scale (a "ruler") for a specific type of risks.

Step 3. The hazard to the technological system from the destructive factors is determined. As a result of item, a dimensional scale is made. The scale can express any value of a destructive factor by the values of a linguistic variable. Next, a formal process shall be submitted for how substantial is the "hazard" to the system from the action of this destructive factor.

Step 4. A formal description of the degree of destruction levels of the technological system from the destructive factors is performed. For this purpose, the linguistic variables are implemented that determine how critical for the technological system is to obtain this or that degree of destruction.

Step 5. In order to determine the relationship between the risk level from the destructive factors and the possible malfunction (or damage) levels of the technological system on the territory adjacent to the object shall be constructed as a mathematical model of the influence of affecting factors on the technological system.

The following logical statement represents mathematical model:

"If there is a destructive factor, malfunction of the technological system is possible, otherwise it is not possible".

This logical statement corresponds to the formal expression:

$$
\text { Если } \underset{\sim}{\mathrm{A}} \text { то } \underset{\sim}{\mathrm{B}} \text { иначе } \underset{\sim}{\mathrm{C}},
$$

where $\underset{\sim}{\mathrm{A}}, \underset{\sim}{\mathrm{B}}, \underset{\sim}{\mathrm{C}}$ are the linguistic variables, which meanings define the following:

$$
\begin{aligned}
& \underset{\sim}{\mathrm{A}} \text { - "DESTRUCTIVE FACTOR"; } \\
& \underset{\sim}{\mathrm{B}} \text { - "SYSTEM HEALTH FAULT"; }
\end{aligned}
$$




\section{C - "NON-HAZARDOUS OBJECT".}

Formal expression seems as a fuzzy matching, defining the relationship between the destructive factor and injuries that can get a technological system when exposed to the appropriate destructive factors:

$$
\underset{\sim}{\phi}=\underset{\sim}{\mathrm{A}} \times \underset{\sim}{\mathrm{B}} \cup \underset{\sim}{\overline{\mathrm{A}}} \times \underset{\sim}{\overline{\mathrm{B}}},
$$

where $X-$ is the Cartesian product operation symbol; $U-$ is the fuzzy sets union operation symbol.

Thus, the probability of affection when exposed to damaging factors to a specific level of hazard is defined as the result of a fuzzy composition:

$$
\underset{\sim}{\mathrm{R}}=\underset{\sim}{\mathrm{Q}} \underset{\sim}{\phi},
$$

where $\mathrm{Q}$ is "the level of hazard of a destructive factor"; $\circ$ is the fuzzy composition operation symbol shown as a maximin product; $\underset{\sim}{\mathrm{R}}$ is the linguistic variable which values of the terms characterize the probability to receive injuries of varying severity, caused by exposure to the technological system destructive factors.

Normalized integral index is used to obtain a clear value of a fuzzy set:

$$
\mathrm{k}(\underset{\sim}{\mathrm{R}})=\sum_{\Delta \alpha} \mathrm{M}\left(\mathrm{R}_{\alpha}\right) \Delta \alpha
$$

where $\mathrm{R}_{a}$ is a set of $\alpha$-level of a fuzzy set $\underset{\sim}{\mathrm{A}}$;

$$
\mathrm{M}\left(\mathrm{R}_{\alpha}\right)=\frac{1}{\mathrm{~m}}\left[\inf _{\alpha \in R} \alpha+\sup _{\alpha \in R} \alpha\right]
$$

inf - greatest lower boundary; sup - greatest upper boundary; $n$ - normalizing factor, defined as follows:

$$
m=n+1,
$$

where $n$ is the half-sum of the minimum and maximum values of the base set.

Step 6. In the same way the hazard coefficients are calculated for each destructive factor. In the event of an accident, a combination of destructive factors (DF) is possible.

To take into account influence of all the DF, a generalized hazard coefficient is introduced, which is calculated as the algebraic sum of fuzzy hazard coefficients for each DF. This happens due to enhancing the action of one destructive factors by another factor.

The "Levels of hazard" scale introduces a qualitative assessment of the hazard degree of defects. Quantity assessment of the emergency hazard level is calculated according to this scale. In general, the developed mathematical model allows determining the level of hazard for an emergency without resorting to statistical data. The developed model helps to create the defeat areas for each object, given its individual characteristics.

\section{Experimental Study}

\subsection{Application of FMEA for Risk Analysis of Process Equipment in Oil and Gas Industry}

As part of the research, during the first phase, the authors obtained the scale for evaluating the probability and impact of risks obtained for quantitative evaluation of $S, O$ and $D$ factors. The appropriate values are shown in Tables 2-4.

Table 2. Scale of significance (consequences) (S) of the risk

\begin{tabular}{llc}
\hline \multicolumn{1}{c}{ Consequence } & \multicolumn{1}{c}{ Meaning of the consequences of a failure } & S coefficient \\
\hline Very insignificant & Failures and defects do not influence performance factors & $1-2$ \\
Insignificant & Defects can be repaired and easily removed & $3-4$ \\
Significant & Failures cause a gradual loss of structural safety and decrease of performance factors & $5-6$ \\
Critical & Defects can cause ruptures and accidents on pipelines. & $7-8$ \\
Catastrophic & Failure threatens the security (hazard to life and health) and is contrary to statutory regulations & $9-10$ \\
\hline
\end{tabular}


Table 3. Scale of foreseeable risk probability $(\mathrm{O})$

\begin{tabular}{|c|c|c|}
\hline Risk probability & Defect occurrence criteria & O coefficient \\
\hline \multirow{2}{*}{ Very low } & Risk of defect is unlikely. & $1-2$ \\
\hline & The probability is almost zero. & \\
\hline Low & Very insignificant probability. & $3-4$ \\
\hline Medium & Medium probability of defect & $5-6$ \\
\hline High & The construction complies with the projects, which faced with a lot of failures in the past. & $7-8$ \\
\hline Very high & Defects are inevitable. & $9-10$ \\
\hline
\end{tabular}

Table 4. Scale of risk detection probability (D)

\begin{tabular}{llc}
\hline $\begin{array}{c}\text { Possibility } \\
\text { of detection }\end{array}$ & The probability of detecting inconsistencies based on provided control operations & D coefficient \\
\hline Very low & Emerging failures cannot be detected (no access or no opportunity to control) & 10 \\
Low & Detecting emerging failures is difficult/technological checks are ineffective & $8-9$ \\
Medium & Failures are difficult to detect during the control and test & $7-6$ \\
Moderate & Detecting inconsistencies is unlikely & $5-4$ \\
High & Detecting failures is easy. & 3 \\
Guaranteed & Failures, if occur, are explicitly recognized (the probability of detection $>95 \%)$ & 1 \\
\hline
\end{tabular}

The coefficient D varies from 10- to defects, which are almost impossible to detect, up to 1- to guarantee the detection of defects.

Then PNR is calculated by the formula (1). The corresponding results are summarized in Table 5 .

Table 5. Results of the registration data on the types of defects and failures with the calculated PNR

\begin{tabular}{|c|c|c|c|c|c|}
\hline No. & - Types of defects and failures & PNR & $\begin{array}{l}\text { Accumulated sum of } \\
\text { the number of defects }\end{array}$ & $\begin{array}{l}\text { PNR per cent per each } \\
\text { type of a defect/failure to } \\
\text { the total sum }\end{array}$ & $\begin{array}{l}\text { Accumulated } \\
\text { per cent }\end{array}$ \\
\hline 1 & $\begin{array}{l}\text { Corrosion and stress-corrosion } \\
\text { damage of equipment }\end{array}$ & 175 & 175 & 27 & 27 \\
\hline 2 & $\begin{array}{l}\text { Failures due to violation of the } \\
\text { technological process performed } \\
\text { on this equipment. }\end{array}$ & 168 & 343 & 26 & 53 \\
\hline 3 & Mechanical wear of the elements & 120 & 463 & 18.5 & 71.5 \\
\hline 4 & Surface wear & 100 & 563 & 15.5 & 87 \\
\hline 5 & $\begin{array}{l}\text { Defect of insulation and protective } \\
\text { covers }\end{array}$ & 84 & 647 & 13 & 100 \\
\hline & Total & 647 & - & 100 & - \\
\hline
\end{tabular}

Further, in accordance with the FMEA scheme, a graphical ranking of PNR failures is made. 


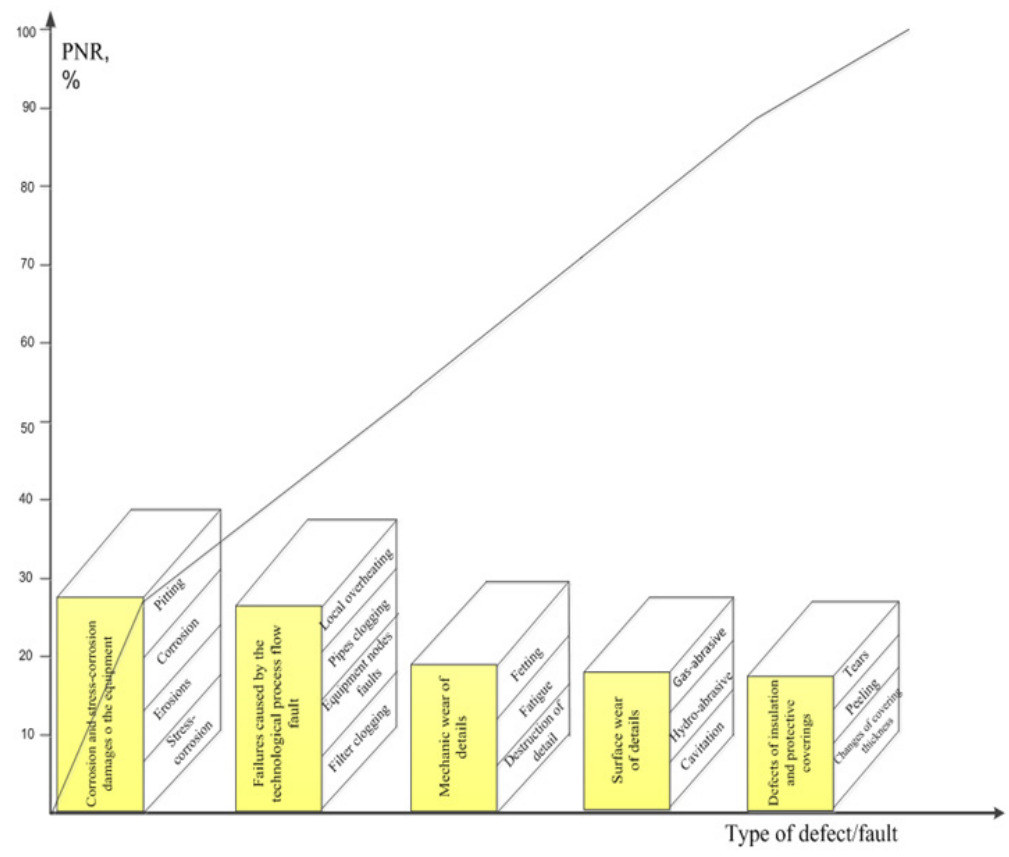

Figure 2. PNR failures ranking

Based on the analysis of the diagram, the main guidelines for the development of corrective actions are listed in the section Discussion.

After constructing diagrams, the main FMEA results were summarized in the summary table, the contents of which is located in Table 6. Based on the analysing the FMEA results, the authors proposed the initial defects control measures, which are also presented in the table. Discussion of the obtained results is presented in the section below.

Table 6. FMEA-analysis of the structure: equipment of oil-refinery industry

\begin{tabular}{|c|c|c|c|c|c|c|c|}
\hline $\begin{array}{l}\text { Type the } \\
\text { potential } \\
\text { defect/failure }\end{array}$ & $\begin{array}{l}\text { Consequences of } \\
\text { the potential } \\
\text { defect/failure }\end{array}$ & $\mathbf{S}$ & $\begin{array}{l}\text { Potential problem of a } \\
\text { defect/failure }\end{array}$ & O & $\begin{array}{l}\text { Initial control } \\
\text { means for defects }\end{array}$ & D & PNR \\
\hline $\begin{array}{l}\text { Corrosion and } \\
\text { stress-corrosion } \\
\text { damage of } \\
\text { equipment: } \\
\text { pitting, } \\
\text { corrosion, } \\
\text { erosion. }\end{array}$ & $\begin{array}{l}\text { The ability of } \\
\text { equipment to } \\
\text { perform its } \\
\text { functions is } \\
\text { preserved, but it } \\
\text { reduces its } \\
\text { effectiveness. } \\
\text { Loss equipment } \\
\text { durability. }\end{array}$ & 5 & $\begin{array}{l}\text { Increased humidity and } \\
\text { aggressive environment, } \\
\text { high pH acidity, } \\
\text { temperature variations. } \\
\text { Peeling of the insulation } \\
\text { coating, low quality of } \\
\text { the insulation coating. } \\
\text { Metal loss (change in } \\
\text { wall thickness). }\end{array}$ & 5 & $\begin{array}{l}\text { Methods for } \\
\text { technological } \\
\text { diagnostics of the } \\
\text { equipment, visual } \\
\text { inspection }\end{array}$ & 7 & 175 \\
\hline $\begin{array}{l}\text { Surface wear: } \\
\text { gas-abrasive, } \\
\text { hydro-abrasive, } \\
\text { cavitation. }\end{array}$ & $\begin{array}{l}\text { Gradual } \\
\text { destruction of the } \\
\text { surface of the } \\
\text { material } \\
\text { equipment, } \\
\text { changing the } \\
\text { geometric shape }\end{array}$ & 4 & $\begin{array}{l}\text { Hydro- and thermal } \\
\text { insulation fault } \\
\text { Fault of the } \\
\text { technological process } \\
\text { performed on this } \\
\text { equipment. } \\
\text { Saline deposit and } \\
\text { deposit of paraffin on } \\
\text { the working bodies of } \\
\text { the equipment. }\end{array}$ & 5 & $\begin{array}{l}\text { Methods for } \\
\text { technological } \\
\text { diagnostics of the } \\
\text { equipment, visual } \\
\text { inspection }\end{array}$ & 5 & 100 \\
\hline
\end{tabular}




\begin{tabular}{|c|c|c|c|c|c|c|c|}
\hline $\begin{array}{l}\text { Type the } \\
\text { potential } \\
\text { defect/failure }\end{array}$ & $\begin{array}{l}\text { Consequences of } \\
\text { the potential } \\
\text { defect/failure }\end{array}$ & $\mathbf{S}$ & $\begin{array}{l}\text { Potential problem of a } \\
\text { defect/failure }\end{array}$ & $\mathbf{O}$ & $\begin{array}{l}\text { Initial control } \\
\text { means for defects }\end{array}$ & D & PNR \\
\hline & $\begin{array}{l}\text { of the rubbing } \\
\text { surfaces. }\end{array}$ & & & & & & \\
\hline $\begin{array}{l}\text { Mechanical wear } \\
\text { of the elements: } \\
\text { fitting, } \\
\text { fatigue. }\end{array}$ & $\begin{array}{l}\text { Equipment } \\
\text { functioning } \\
\text { faults, } \\
\text { Mechanical } \\
\text { destruction of the } \\
\text { elements. } \\
\text { (destruction of an } \\
\text { element because } \\
\text { of the wear). }\end{array}$ & 4 & $\begin{array}{l}\text { Outer mechanical } \\
\text { impact } \\
\text { High specific load, } \\
\text { movement speed. } \\
\text { Chronological aging } \\
\text { Failure to comply with } \\
\text { production technology } \\
\text { equipment (low-quality } \\
\text { casting, welding, etc.). } \\
\text { Lack of effective input } \\
\text { control. }\end{array}$ & 5 & $\begin{array}{l}\text { Methods for } \\
\text { technological } \\
\text { diagnostics of the } \\
\text { equipment, visual } \\
\text { inspection }\end{array}$ & 6 & 120 \\
\hline $\begin{array}{l}\text { Failures due to } \\
\text { violation of the } \\
\text { technological } \\
\text { process } \\
\text { performed on } \\
\text { this equipment } \\
\text { (local unit } \\
\text { overheat, pipes } \\
\text { coking, filter }\end{array}$ & $\begin{array}{l}\text { Manufacture of } \\
\text { substandard } \\
\text { product or } \\
\text { equipment } \\
\text { malfunction } \\
\text { (damage, } \\
\text { equipment units } \\
\text { failure }\end{array}$ & & $\begin{array}{l}\text { Personnel lacking the } \\
\text { required qualification. } \\
\text { Human factor and } \\
\text { discrepancy with the } \\
\text { technology } \\
\text { High wear level } \\
\text { Deterioration of the } \\
\text { working bodies with the } \\
\text { contaminants }\end{array}$ & & $\begin{array}{l}\text { Methods for } \\
\text { technological }\end{array}$ & & \\
\hline $\begin{array}{l}\text { clogging and } \\
\text { separation } \\
\text { elements } \\
\text { clogging in the } \\
\text { membrane } \\
\text { separation units, } \\
\text { contamination of } \\
\text { the catalyst in the } \\
\text { reaction } \\
\text { machine, etc. ) }\end{array}$ & $\begin{array}{l}\text { thread stripping, } \\
\text { malfunction of } \\
\text { control elements, } \\
\text { breaking of the } \\
\text { element } \\
\text { connection, } \\
\text { drive failure, } \\
\text { cables tear) }\end{array}$ & 7 & $\begin{array}{l}\text { Wear of the working } \\
\text { bodies because of } \\
\text { cloggage with } \\
\text { mechanical admixtures } \\
\text { Operation faults } \\
\text { Violation of the } \\
\text { production process } \\
\text { Natural disasters. } \\
\text { Violation of } \\
\text { rhythms/rules and } \\
\text { regulation of technical } \\
\text { operation }\end{array}$ & 4 & $\begin{array}{l}\text { diagnostics of the } \\
\text { equipment, visual } \\
\text { inspection }\end{array}$ & 6 & 168 \\
\hline $\begin{array}{l}\text { Defects of } \\
\text { isolation and } \\
\text { protective covers } \\
\text { (peeling, } \\
\text { variation of } \\
\text { cover thickness, } \\
\text { breaks, } \\
\text { cuts and tears). }\end{array}$ & $\begin{array}{l}\text { Reduce of wall } \\
\text { thickness of body, } \\
\text { bottom and tube } \\
\text { sheets. }\end{array}$ & 4 & $\begin{array}{l}\text { Violation of } \\
\text { technological regimes } \\
\text { during manufacturing } \\
\text { and transportation. } \\
\text { Low quality of } \\
\text { insulation coating. } \\
\text { Violation of the rules for } \\
\text { production and } \\
\text { technology of insulation } \\
\text { and building work } \\
\text { (abnormal temperature } \\
\text { of piping and materials, } \\
\text { poor cleaning of the } \\
\text { pipeline surface, failure } \\
\text { of coating modes, } \\
\text { damage during } \\
\text { transportation and } \\
\text { installation) }\end{array}$ & 7 & $\begin{array}{l}\text { Methods for } \\
\text { technological } \\
\text { diagnostics of the } \\
\text { equipment, visual } \\
\text { inspection }\end{array}$ & 3 & 84 \\
\hline
\end{tabular}




\begin{tabular}{|c|c|c|c|c|c|c|c|}
\hline $\begin{array}{l}\text { Type the } \\
\text { potential } \\
\text { defect/failure }\end{array}$ & $\begin{array}{l}\text { Consequences of } \\
\text { the potential } \\
\text { defect/failure }\end{array}$ & $\mathbf{S}$ & $\begin{array}{l}\text { Potential problem of a } \\
\text { defect/failure }\end{array}$ & $\mathbf{O}$ & $\begin{array}{l}\text { Initial control } \\
\text { means for defects }\end{array}$ & D & PNR \\
\hline & & & $\begin{array}{l}\text { The impact of soil } \\
\text { particles when laying, } \\
\text { backfilling and using } \\
\text { the pipeline. }\end{array}$ & & & & \\
\hline
\end{tabular}

Discussion of the obtained results is presented in the section below.

\subsection{Discussion of the Results}

In accordance with the data obtained, it shall be noted that the most critical equipment failures in oil and gas industry are the following:

- Corrosion and stress-corrosion damage: pitting, corrosion, erosion.

- Failures due to fault of the technological process performed on this equipment.

While operated, the technical condition of parts of the process equipment is exposed to the continuous damaging effects. Having reached the critical level, the damage accumulated during the operation, result in the destruction of the working condition of the equipment, and therefore to its failure entailing other consequences.

The main criterion for determining the reliability of the equipment is the safety of its operation, i.e. the exclusion of sudden failures of elements. The most important measure of safety is the quantification of risk parameters characterizing the probability of failure. FMEA tool is an effective method for assessing and reducing the risk probability.

Designed ranked list of failures causes for oil refinery equipment will allow developing the effective measures to improve reliability.

\section{Conclusion}

The present study obtained results suggesting that the FMEA method in conjunction with the supporting fuzzy logic method can be effectively used for risk assessment in oil refineries and oil and gas industry as a whole. Of course, by itself, the risk assessment is not the ultimate goal of the research. Important is the integration of the derived methods into the risk management and control system for reliability of oil and gas productions. Despite the fact that at present moment, intelligent analysis technologies are investigated deeply enough, and the experience of their use proves their effectiveness in the application in tasks, setting of which can be reduced to formulating problems of modelling, forecasting, optimization and classification, the need for their further improvement is evident. The reason for that is the modern requirements for accuracy and speed of decision-making, which are constantly growing due to increasing demands to ensure the correctness and reliability of prediction and comprehensive diagnostics equipment, process simulation efficiency and increasing the risk assessments of emergencies, as well as the improper use of technological machines.

The considered methods and models can be used to build algorithmic core of high-performance intelligent control systems, diagnostics and reliability for enterprise production, transportation and processing of oil and gas (Bukhtoyarov et al., 2012). In future, we suppose to develop methods for the integration of different information technologies and methods of analysis (FMEA, fuzzy logic, artificial neural networks). We believe that they can be used for efficient simultaneous parallel solution to complex problems of forecasting, modelling and classification, to which obviously a significant amount of problems for diagnosis, prediction of reliability and analysis of the state of the process equipment and technology oil and gas systems can be reduced. Such techniques can significantly improve the efficiency of solving these problems, which in turn improves the performance indicators and safety of the production as a whole, which is especially important in the current conditions.

\section{References}

Aras, F., Karakaş, E., \& Biçen, Y. (2014). Fuzzy logic-based user interface design for risk assessment considering human factor: A case study for high-voltage cell. Safety science, 70, 387-396. http://dx.doi.org/10.1016/j.ssci.2014.07.013

Barends, D. M., Oldenhof, M. T., Vredenbregt, M. J., \& Nauta, M. J. (2012). Risk analysis of analytical validations by probabilistic modification of FMEA. Journal of pharmaceutical and biomedical analysis, 64, 
82-86. http://dx.doi.org/10.1016/j.jpba.2012.02.009

Bukhtoyarov, V., Semenkin, E., \& Shabalov, A. (2012). Neural networks ensembles approach for simulation of solar arrays degradation process. Hybrid Artificial Intelligent Systems. Springer Berlin Heidelberg, 186-195.

Burgherr, P., Eckle, P., \& Hirschberg, S. (2012). Comparative assessment of severe accident risks in the coal, oil and natural gas chains. Reliability Engineering \& System Safety, 105, 97-103. http://dx.doi.org/10.1016/j.ress.2012.03.020

Chen-qin, H. E., \& Yue, W. A. N. G. (2012). Study on application of FMEA in risk analysis of ethylene tank. Journal of Safety Science and Technology, 1, 34.

Farrell, A. E., \& Brandt, A. R. (2006). Risks of the oil transition. Environmental Research Letters, 1(1), 014004. http://dx.doi.org/10.1088/1748-9326/1/1/014004

Guzman, A., \& Asgari, B. (2014). A cost-benefit analysis of investing in safety and risk engineering: The case of Oil \& Gas transportation services by pipelines. In Management of Engineering \& Technology (PICMET), 2014 Portland International Conference on (pp. 1633-1645). IEEE.

Hekmatpanah, M., Shahin, A., \& Ravichandran, N. (2011). The application of FMEA in the oil industry in Iran: The case of four litre oil canning process of Sepahan Oil Company. African Journal of Business Management, 5(8), 3019-3027.

Khaleghi, S., Givehchi, S., \& Karimi, S. (2013). Fuzzy Risk Assessment and Categorization, based on Event Tree Analysis (ETA) and Layer of Protection Analysis (LOPA): Case Study in Gas Transport System. World Applied Programming, 3(9).

Khan, F. I., Haddara, M., \& Krishnasamy, L. (2008). A new methodology for risk-based availability analysis. Reliability, IEEE Transactions on, 57(1), 103-112. http://dx.doi.org/10.1109/TR.2007.911248

Khan, F. I., Sadiq, R., \& Husain, T. (2002). Risk-based process safety assessment and control measures design for offshore process facilities. Journal of hazardous materials, 94(1), 1-36. http://dx.doi.org/10.1016/S0304-3894(02)00004-3

Medikonda, B. S., Ramaiah, P. S., \& Gokhale, A. A. (2011). FMEA and Fault Tree based Software Safety Analysis of a Railroad Crossing Critical System. Global Journal of Computer Science and Technology, $11(8), 57-58$.

Mendel, J. M. (2001). Uncertain rule-based fuzzy logic system: Introduction and new directions.

Petrovsky, E., \& Elrikh, Yu. (2012). Valuation techniques and risk analysis in order to improve the efficiency of repair programs of electric power industry of the Russian Federation. Natural and Technical Sciences, (6), 302-306.

Saidi, E., Anvaripour, B., Jaderi, F., \& Nabhani, N. (2014). Fuzzy risk modeling of process operations in the oil and gas refineries. Journal of Loss Prevention in the Process Industries, 30, 63-73. http://dx.doi.org/10.1016/j.jlp.2014.04.002

Shahriar, A., Sadiq, R., \& Tesfamariam, S. (2012). Risk analysis for oil \& gas pipelines: A sustainability assessment approach using fuzzy based bow-tie analysis. Journal of Loss Prevention in the Process Industries, 25(3), 505-523. http://dx.doi.org/10.1016/j.jlp.2011.12.007

Skogdalen, J. E., Utne, I. B., \& Vinnem, J. E. (2011). Developing safety indicators for preventing offshore oil and gas deepwater drilling blowouts. Safety science, 49(8), 1187-1199. http://dx.doi.org/10.1016/j.ssci.2011.03.012

Smith, D. J. (2011). Reliability, Maintainability and Risk 8e: Practical Methods for Engineers Including Reliability Centred Maintenance and Safety-Related Systems. Elsevier.

Tweeddale, M. (2003). Managing risk and reliability of process plants. Gulf Professional Publishing.

Xiao, N., Huang, H. Z., Li, Y., He, L., \& Jin, T. (2011). Multiple failure modes analysis and weighted risk priority number evaluation in FMEA. Engineering Failure Analysis, 18(4), 1162-1170. http://dx.doi.org/10.1016/j.engfailanal.2011.02.004

Yousef, M. A., Al-Omairi, K., Al-Shehri, A. I., \& Kakpovbia, A. E. (2014, July). Improvement of the Welding Inspection Process for Projects in the Oil and Gas Industry Using Six Sigma Methodology. In ASME 2014 12th Biennial Conference on Engineering Systems Design and Analysis (pp. 
V003T14A012-V003T14A012). American Society of Mechanical Engineers.

Yuhua, D., \& Datao, Y. (2005). Estimation of failure probability of oil and gas transmission pipelines by fuzzy fault tree analysis. Journal of loss prevention in the process industries, 18(2), 83-88. http://dx.doi.org/10.1016/j.jlp.2004.12.003

Zadeh, L. A. (1997). Toward a theory of fuzzy information granulation and its centrality in human reasoning and fuzzy logic. Fuzzy sets and systems, 90(2), 111-127. http://dx.doi.org/10.1016/S0165-0114(97)00077-8

Zio, E. (2009). Reliability engineering: Old problems and new challenges. Reliability Engineering \& System Safety, 94(2), 125-141. http://dx.doi.org/10.1016/j.ress.2008.06.002

\section{Copyrights}

Copyright for this article is retained by the author(s), with first publication rights granted to the journal.

This is an open-access article distributed under the terms and conditions of the Creative Commons Attribution license (http://creativecommons.org/licenses/by/3.0/). 